\title{
Shoot growth of Merlot and Cabernet Sauvignon grapevine varieties
}

\author{
Marcelo Borghezan ${ }^{(1)}$, Olavo Gavioli(2), Hamilton Justino Vieira( ${ }^{(3)}$ and Aparecido Lima da Silva(1) \\ (1)Universidade Federal de Santa Catarina, Centro de Ciências Agrárias, Departamento de Fitotecnia, Rodovia Admar Gonzaga, no 1.346, \\ CEP 88040-900 Florianópolis, SC, Brazil. E-mail: mborghezan@hotmail.com, alsilva@cca.ufsc.br (2)Cooperativa Agrícola de São \\ Joaquim - SANJO, Rua Francilicio Pinto Arruda, № 1.101, CEP 88600-000 São Joaquim, SC, Brazil. E-mail: olavogavioli@hotmail.com \\ ${ }^{(3)}$ Empresa de Pesquisa Agropecuária e Extensão Rural de Santa Catarina, Centro de Informações de Recursos Ambientais e de \\ Hidrometeorologia de Santa Catarina, Rodovia Admar Gonzaga, no 1.347, Itacorubi, Caixa Postal 502, CEP 88034-901 Florianópolis, SC, \\ Brazil. E-mail: vieira@epagri.sc.gov.br
}

\begin{abstract}
The objective of this work was to evaluate shoot growth of the grapevine varieties Merlot and Cabernet Sauvignon, during 2006/2007, and Cabernet Sauvignon, during 2008/2009, in São Joaquim, SC, Brazil. The experiment was carried out in a commercial vineyard trained on a vertical trellis system. The shoots of the central part of the plants were selected, and the lengths from the base to the apex of 20 shoots per cultivar were evaluated. In 2006/2007, monitoring began at pruning, on $9 / 15 / 2006$, and ended on $2 / 6 / 2007$, totalizing 144 days of evaluation. During the 2008/2009 cycle, phenology and shoot growth for 'Cabernet Sauvignon' were assessed from grape development (1/13/2009) (pea-sized grapes) until shoot vegetative growth had ceased. Budburst occurred in the second half of September, and shoot-growth cessation occurred during ripening. Higher growth rates (about $4 \mathrm{~cm}$ per day) were observed in pre- and post-flowering, followed by reduction due to the competition for photosynthates for the formation of flowers and bunches. Temperature and photoperiod induce grapevine shoots to cease growth in the highland regions of Santa Catarina State, Brazil.
\end{abstract}

Index terms: Vitis vinifera, photoperiod, temperature, vegetative growth.

\section{Crescimento de ramos das variedades de videira Merlot e Cabernet Sauvignon}

Resumo - O objetivo deste trabalho foi avaliar o crescimento de ramos das variedades de videira Merlot e Cabernet Sauvignon, em 2006/2007, e Cabernet Sauvignon, em 2008/2009, em São Joaquim, SC. O experimento foi realizado em um vinhedo comercial conduzido em espaldeira. Foram selecionados ramos da parte central das plantas e foi avaliado o comprimento da base até o ápice de 20 ramos por cultivar. Em 2006/2007, o monitoramento iniciou-se a partir da poda, em 15/9/2006, e foi encerrado em 6/2/2007, o que totalizou 144 dias de avaliação. Durante o ciclo 2008/2009, avaliou-se a fenologia e o crescimento dos ramos para 'Cabernet Sauvignon' a partir do desenvolvimento das bagas (13/1/2009) (bagas em tamanho de ervilha) até todos os ramos não apresentarem crescimento vegetativo. A brotação iniciou-se na segunda quinzena de setembro, e a paralisação do crescimento dos ramos ocorreu durante o período de maturação. Maiores taxas de crescimento (cerca de $4 \mathrm{~cm}$ por dia) foram observadas em pré e pós-floração, seguidas de redução em virtude da competição por fotoassimilados para a formação de flores e cachos. A temperatura e o fotoperíodo induzem a paralisação de crescimento dos ramos nas regiões de altitude de Santa Catarina.

Termos para indexação: Vitis vinifera, fotoperíodo, temperatura, crescimento vegetativo.

\section{Introduction}

The grapevine (Vitis vinifera L.) vegetative cycle begins at budburst and ends at the end of the growth phase, when the development of the plant ceases and the dormancy stage begins (Pouget, 1972; Chao et al., 2007). The vegetative growth phase is dependent on several factors, and meteorological variables have an essential role in the control of grapevine development (Pouget, 1972; Andreini et al., 2009; Garris et al., 2009; Olsen, 2010).
The maintenance of the equilibrium among vegetative growth (leaves), productive capacity (clusters), and reserve accumulation (shoots and roots) provides the necessary conditions for triggering the physiological processes of ripening (Petrie et al., 2000). Depending on the climatic conditions, the vegetative growth of the shoots ceases during veraison (Leeuwen et al., 2004; Cloete et al., 2006). This behavior benefits the metabolic and biochemical processes, by predominantly transferring compounds produced by photosynthesis, for berry ripening (Fournioux, 1997;

Pesq. agropec. bras., Brasília, v.47, n.2, p.200-207, fev. 2012 
Koundouras et al., 1999; Robinson \& Davies, 2000; Conde et al., 2007). The identification of this period and of its inducing factors could provide indicators of the adaptation of a variety to the planting locality (Garris et al., 2009).

Shoot growth cessation requires the suspension of cell division at the apical meristems and the paralyzation of internodal elongation (Chao et al., 2007; Garris et al., 2009). In the grapevine, this mechanism coincides with the induction of bud dormancy, occurring before leaf senescence (Victor et al., 2010). The alterations in the meteorological variables act as inductors of ecophysiological adaptation (Leeuwen et al., 2004; Heide \& Prestrud, 2005; Garris et al., 2009). However, the factors responsible for this induction vary for each growing condition. In the Mediterranean region, water deficit can cause shoot growth cessation during grape ripening (Tregoat et al., 2002; Leeuwen et al., 2004; Gachons et al., 2005) or even before veraison (Koundouras et al., 1999).

Growth cessation is a complex mechanism and is related to other factors, besides water availability, such as temperature (Pouget, 1972; Hendrickson et al., 2004; Heide \& Prestrud, 2005; Heide, 2008; Andreini et al., 2009) and photoperiod (Fennell \& Hoover, 1991; Wake \& Fennell, 2000; Heide, 2008; Andreini et al., 2009; Garris et al., 2009). Recently, it has been suggested that those factors may be synergistic, inducing biochemical pathways of hormonal regulation, which control the completion of the meristematic activity of the shoots (Garris et al., 2009; Olsen, 2010; Tanino et al., 2010). Temperature affects the cell metabolism, carbon accumulation and other biochemical processes (Tanino et al., 2010). The variation in the photoperiod, including long nights, affects the phytochromes (photoreceptors), which control signal transduction in order to regulate shoot growth (Chao et al., 2007; Olsen, 2010; Tanino et al., 2010; Victor et al., 2010).

In the Brazilian highland regions, where wine production is still incipient, research on grapevine phenological behavior and growth habit, supported by climatological data, can be used to define the varieties better adapted to the production of high-quality wines.

The objective of this work was to evaluate shoot growth of the grapevine varieties Merlot and Cabernet Sauvignon, during 2006/2007, and Cabernet
Sauvignon, during 2008/2009, in São Joaquim, SC, Brazil.

\section{Materials and Methods}

The experiment was carried out in a commercial vineyard of the winery Villa Francioni Agro Negócios S.A., in São Joaquim, Santa Catarina State, Brazil $\left(28^{\circ} 15^{\prime} 13^{\prime \prime} \mathrm{S}, 49^{\circ} 57^{\prime} 02^{\prime \prime} \mathrm{W}\right.$, at $1,293 \mathrm{~m}$ of altitude). The climate of the region is classified, according to Köppen, as Cfb. Planting was carried out in 2002, on Paulsen 1103 rootstock, conducted in a vertical trellis system, with $3.0 \times 0.75-\mathrm{m}$ spacing, in a north-south orientation. After budburst, the shoots were trained on vertical position for better canopy disposition. Pruning was done leaving two buds per spur, in a unilateral spur system. The number of buds was determined by the winery in order to limit production, maintaining around 16 buds per plant for both varieties. Shoot growth was evaluated in plants without shoot topping, but with lateral shoots (feminels).

The meteorological data, including precipitation, temperature (minimum, mean and maximum) and photoperiod, were obtained from the meteorological station at the Centro de Informações de Recursos Ambientais e de Hidrometeorologia de Santa Catarina, located at the experimental station of Empresa de Pesquisa Agropecuária e Extensão Rural de Santa Catarina, at approximately $2,800 \mathrm{~m}$ from the experimental area. The thermoperiod (daily thermal amplitude) was estimated by the difference between maximum and minimum temperatures.

Phenology was evaluated according to Leeuwen et al. (2004). In order to define the phenological stages of the grapevine, the BBCH scale (Lorenz et al., 1995) was used. The phenological stages described were: pruning, budburst (BBCH 07), flowering (BBCH 65), beginning of ripening $(\mathrm{BBCH} 81)$, veraison $(\mathrm{BBCH} 85)$ and harvest.

Shoot growth was evaluated by the random selection of 20 buds (one per spur) in the median region of the plants. The shoots were identified and evaluated since the beginning of development (budburst), measuring from the shoot base insertion to the apical meristem. The evaluations were done with a fillet gauge following the shoot curvatures during vegetative growth. The average growth rate for each of the evaluated periods and for the total growth cycle from the collected data 
was estimated by dividing the obtained length by the number of days. The relationship between photoperiod and growth rate for 'Cabernet Sauvignon' was determined in the 2006/2007 and 2008/2009 seasons.

Shoot growth evaluation began at pruning, which was carried out on 9/15/2006 until 2/6/2007, totalizing 144 days. During the 2008/2009 season, phenology and shoot growth were evaluated for the Cabernet Sauvignon variety, as previously described. Shoot growth was evaluated weekly from the grape development phenological stage (1/13/2009) (pea-sized grapes $\mathrm{BBCH}$ 75) until shoot vegetative growth had ceased (2/25/2009), totalizing 43 days. Monitoring of the climatological variables (minimum, mean and maximum temperatures and rainfall) was done at an automatic meteorological station located in the vineyard.

The experimental design used was a completely randomized block, with 20 replicates (shoots). The data were evaluated using the software Statistica, version 6.0 (Statsoft, 2001), by polynomial regression analysis, at $5 \%$ probability.
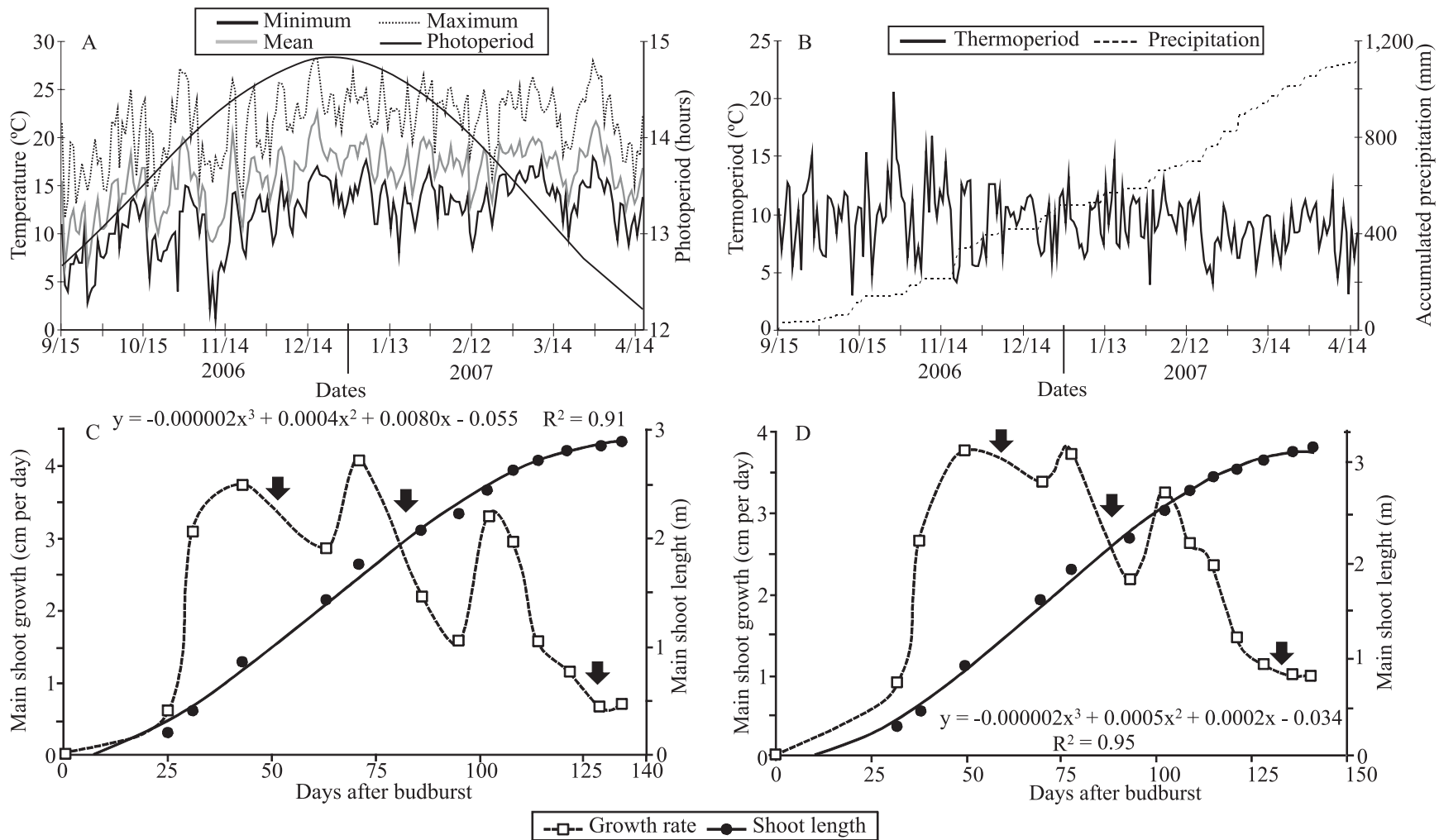

Figure 1. The 2006/2007 grapevine vegetative cycle in São Joaquim, Santa Catarina, Brazil. A, daily temperature variation (minimum, maximum and mean) and photoperiod; B, daily variation of thermoperiod and precipitation; C and D, length and growth rates of the main shoots of 'Cabernet Sauvignon' and 'Merlot', respectively. The arrows indicate the flowering, fruiting and veraison dates.

\section{Results and Discussion}

In the 2006/2007 season, meteorological data showed that the grapevine vegetative cycle occurred under mild median temperature $\left(16.1^{\circ} \mathrm{C}\right)$ and low thermal amplitude $\left(9.4^{\circ} \mathrm{C}\right)$. The average maximum and minimum temperatures during this period were $21.6^{\circ} \mathrm{C}$ and $12.2^{\circ} \mathrm{C}$, respectively (Figure 1). The maximum temperature of the thermoperiod was $14.8^{\circ} \mathrm{C}$ in $1 / 16 / 2007$ and the minimum was $3.9^{\circ} \mathrm{C}$ in $1 / 29 / 2007$. Rainfall was well distributed during the vegetative cycle, accumulating $1,112 \mathrm{~mm}$ between budburst and harvest.

In the 2006/2007 season, the climatological variables did not affect plant development and ripening was only affected by excessive rainfall, when compared to previous productive cycles (Falcão et al., 2008; Gris et al., 2010). No variation was observed in relation to the historical averages, with the exception of the number of rainy days and the precipitation volume during grape ripening (Falcão et al., 2008; Borghezan et al., 2011). 
The maximum temperatures were around $23^{\circ} \mathrm{C}$ and the medium temperatures approximately $17^{\circ} \mathrm{C}$, with minimum temperatures varying between 8 and $13^{\circ} \mathrm{C}$; the photoperiod was reduced when shoot growth ceased (mid-January 2007) (Figure 1).

In 2006/2007, pruning was done in mid-September, with flowering beginning at the end of November. Ripening began at the end of January, around 60 days after flowering. Harvesting for 'Merlot' was done at the beginning of April and for 'Cabernet Sauvignon' two weeks later (Table 1). For both varieties, harvesting was done when the soluble solid content was over $21^{\circ}$ Brix. During the 2008/2009 season, a longer delay was observed regarding the beginning of grape ripening, and the grapes were harvested with $23.9^{\circ}$ Brix.

The differences in the number of days between the phenological stages are similar to those reported for 'Cabernet Sauvignon' and 'Merlot' in vineyards in the Bordeaux region of France (Leeuwen et al., 2004). However, in the Northern hemisphere, budburst occurs at the beginning of April, with harvesting at the end of September. Those results are closer to the ones observed in vineyards in São Joaquim, SC, Brazil (Falcão et al., 2008; Gris et al., 2010; Borghezan et al., 2011). In the "Serra Gaúcha" (mild climate), the largest grape

Table 1. Grapevine phenological stages in São Joaquim, Santa Catarina, Brazil, during the 2006/2007 and 2008/2009 seasons.

\begin{tabular}{lccc}
\hline Phenological stage & Date & № accumulated days & Days after budburst \\
\hline Pruning & \multicolumn{2}{c}{ 'Cabernet Sauvignon' 2006/2007 season } \\
Budburst & $9 / 15$ & 0 & - \\
Flowering & $9 / 25$ & 10 & 0 \\
Beginning of ripening & $11 / 21$ & 67 & 57 \\
Veraison & $1 / 22$ & 129 & 119 \\
Harvest & $1 / 31$ & 138 & 128 \\
\hline & $4 / 17$ & 214 & 204 \\
Pruning & \multicolumn{4}{c}{ 'Merlot' 2006/2007 season } \\
Budburst & $9 / 15$ & 0 & - \\
Flowering & $9 / 18$ & 3 & 0 \\
Beginning of ripening & $11 / 21$ & 67 & 64 \\
Veraison & $1 / 21$ & 128 & 125 \\
Harvest & $1 / 31$ & 138 & 135 \\
& $4 / 3$ & 200 & 197 \\
Pruning & \multicolumn{1}{c}{ Cabernet Sauvignon' 2008/2009 season } \\
Budburst & $9 / 20$ & 0 & - \\
Flowering & $9 / 27$ & 7 & 0 \\
Beginning of ripening & $12 / 12$ & 80 & 73 \\
Veraison & $2 / 17$ & 150 & 143 \\
Harvest & $2 / 25$ & 158 & 151 \\
\hline & $4 / 18$ & 210 & 203 \\
\hline
\end{tabular}

producing region in Brazil, budburst occurs at the beginning of September, with harvesting at the end of March (Mota et al., 2008). In comparison to the Santa Catarina highlands (cold climate), this cycle is shorter and more precocious.

The average length of the main shoots of the Cabernet Sauvignon and Merlot varieties was similar until the beginning of grape ripening (Figure 1). The data were adjusted according to the polynomial model, in which a lower length increase was observed in the first weeks after budburst, with linear growth after the twentieth day and growth stabilization approximately 120 days later. At the beginning of ripening (around 130 days), growth reduction in the main shoots was observed, with no growth during grape ripening.

The pattern of vegetative development is compatible to descriptions of the activation of the dormancy mechanism (Victor et al., 2010). During flowering and at the beginning of grape formation, a reduction in the shoot growth rate was observed for both varieties (Figure 1). This pattern is possibly associated to the competition for photoassimilates between the reproductive and vegetative structures (Vasconcelos et al., 2009).

The average shoot length was $2.90 \mathrm{~m}$ for 'Cabernet Sauvignon' and $3.22 \mathrm{~m}$ for 'Merlot'. Since the beginning of grape ripening, the shoots started lignification, shoot tips and lateral shoots ceased growth, and the leaves became senescent. Shoot maturation (reserve accumulation) coincident with grape ripening could result in competition between the vegetative and reproductive organs of the vine (Cloete et al., 2006).

Shoot growth rates followed the same pattern for both varieties. After budburst, the observed values were low $(5.0 \mathrm{~cm}$ per week), but around the thirtieth day shoot growth increased to approximately $25.0 \mathrm{~cm}$ per week (36 $\mathrm{mm}$ per day). This growth rate was, in general, maintained until 110 days after budburst in both varieties; however, after this phase, it began to decrease to the levels of the initial development period. The growth rate was significantly reduced from $1 / 11 / 2007$ to $1 / 17 / 2007$ (118 to 124 days) and did not restart until the end of the evaluation. According to Leeuwen et al. (2004), the shoots cease growth when the growth rate is less than $5 \mathrm{~mm}$ per day, which occurs during grape ripening in French vineyards, although, in that case, the responsible factor was water availability and harvesting was done between 45 and 60 days after veraison. 
The mean growth rate was $14.0 \mathrm{~cm}$ per week for 'Cabernet Sauvignon' and $16.0 \mathrm{~cm}$ per week for 'Merlot'. During veraison, the mean shoot growth was less than $10 \mathrm{~mm}$ per day. These results are indicators that growth cessation occurred during grape ripening (Table 1).

A similar shoot growth behavior to the one observed in the present study was described by Smithyman et al. (1997), and a similar pattern was reported for 'Pinot Noir' and 'Pinot Gris' planted under greenhouse conditions (Petrie et al., 2000; Lenz et al., 2009).

During the $2008 / 2009$ season, the mean temperature was $13.9^{\circ} \mathrm{C}$, with a minimum of $9.2^{\circ} \mathrm{C}$ and a maximum of $21.0^{\circ} \mathrm{C}$ between budburst and harvest (Figure 2). The mean thermoperiod was around $11.8^{\circ} \mathrm{C}$ and the total rainfall was $1,474 \mathrm{~mm}$. During grape ripening (2/25/2009 to 4/18/2009), a well distributed rain volume of $95 \mathrm{~mm}$ was registered. Reduction in photoperiod
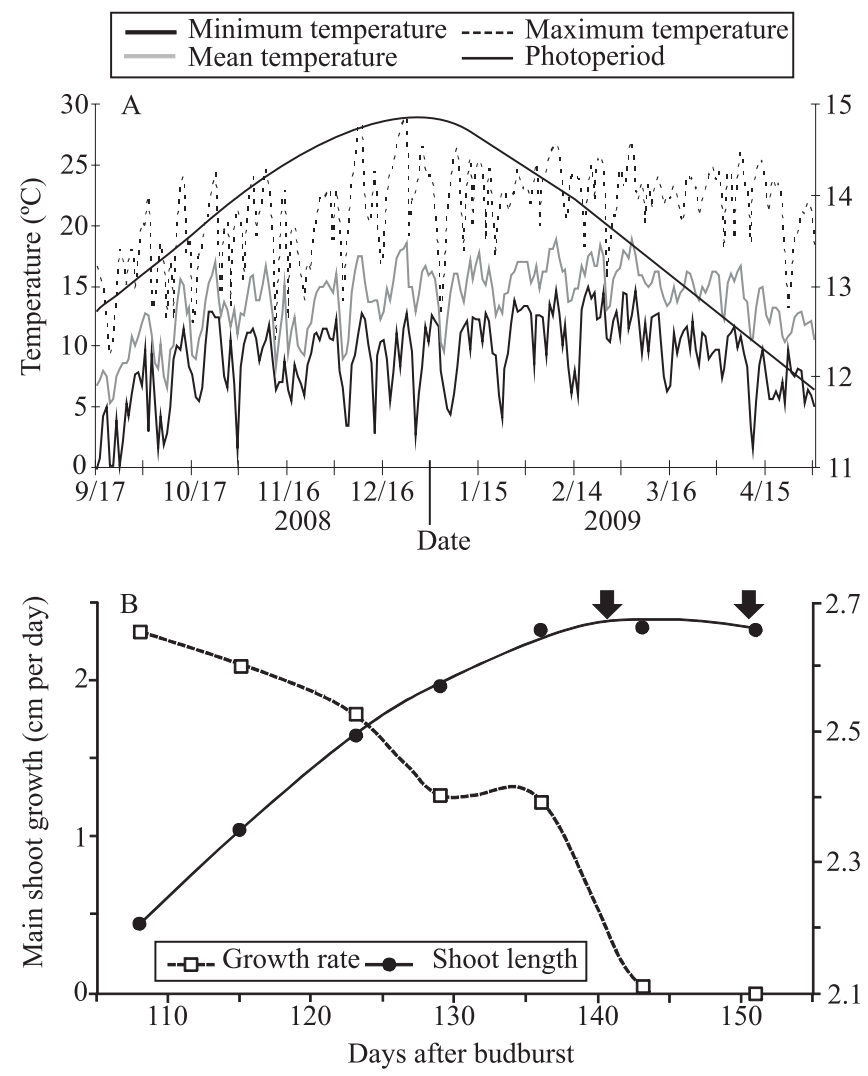

Figure 2. The 2008/2009 grapevine vegetative cycle in São Joaquim, Santa Catarina, Brazil. A, daily temperature variation (minimum, maximum and mean); B, length and growth rate of the main shoot of 'Cabernet Sauvignon'. The arrows indicate shoot growth cessation and veraison $(2 / 25 / 2009$ - 151 days after budburst). coincides with shoot cessation growth of 'Cabernet Sauvignon' (Figure 3).

In this season, shoot growth cessation occurred between $2 / 3 / 2009$ and $2 / 10 / 2009$. Before this period, minimum temperatures around $4.1^{\circ} \mathrm{C}(1 / 22 / 2009)$ were observed. From $2 / 13 / 2009$ to $2 / 15 / 2009$, minimum temperatures were between 6.0 and $8.0^{\circ} \mathrm{C}$. Complete shoot growth cessation was observed after 2/17/2009 (143 days after budburst), coinciding with the beginning of berry ripening. The mean shoot growth during the $2008 / 2009$ season was $2.66 \mathrm{~m}$. The average rate of shoot growth was drastically reduced from 136 and 143 days after budburst, respectively, indicating that the vegetative development ceased with the beginning of berry ripening (Figures 2 and 3 ).

The mean length of the main shoot is similar to the values found for 'Cabernet Sauvignon' $(3.43 \mathrm{~m})$ and 'Merlot' $(3.76 \mathrm{~m})$ in a French vineyard by Leeuwen et al. (2004), who reported that growth ceased around 170 days after budburst. Lower shoot growth was

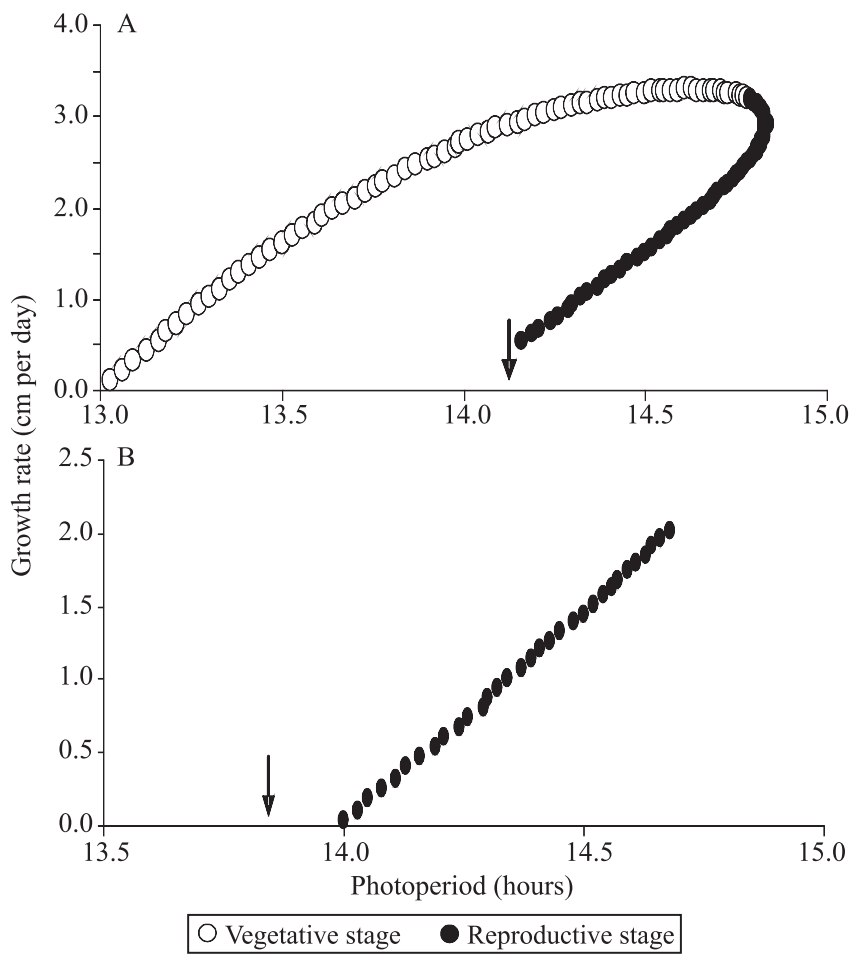

Figure 3. Relationship between photoperiod and growth rate for 'Cabernet Sauvignon': A, during the 2006/2007 season with veraison on $1 / 31$ (128 days after budburst); and B, during the 2008/2009 season with veraison on 2/25 (151 days after budburst), in São Joaquim, Santa Catarina, Brazil. The arrows indicate veraison dates. 
described for 'Cabernet Sauvignon' (Hunter \& Visser, 1990) and 'Shiraz' (Cloete et al., 2006) cultivated in South Africa, and for 'Seyval Blanc' in the USA (Smithyman et al., 1997).

The climatic conditions observed in São Joaquim, SC, Brazil, for both seasons possibly stimulated the reduction of the apical meristem activity during the final phase of grape formation (January and beginning of February). Therefore, shoot growth cessation is related to senescence in the apical region (Pouget, 1972; Cloete et al., 2006; Chao et al., 2007).

Maximum growth rate was observed in early December, about 15 days before the occurrence of increased photoperiod (14.8 hours on $12 / 23$ ). This period coincides with the beginning of the reproductive stage, the reduction of the photoperiod and the slowdown in the growth rates. During the 2008/2009 season, the relationship between the reduction in photoperiod and shoot growth cessation was confirmed (Figure 3). Moreover, the occurrence of low temperatures caused dislocation of the production cycle in São Joaquim, SC, Brazil.

Shoot growth cessation is a complex physiological process that is not fully understood, either in relation to the biochemical alterations in the internal tissues or to the climatic variables (Heide, 2008; Garris et al., 2009; Tanino et al., 2010; Victor et al., 2010). Several authors reported that temperature, water and nutrient availability play important roles in the induction of shoot growth cessation (Koundouras et al., 1999; Leeuwen et al., 2004; Coipel et al., 2006). In addition, photoperiod (Wake \& Fennell, 2000; Heide, 2008; Garris et al., 2009; Victor et al., 2010) and probably thermoperiod (Olsen, 2010; Tanino et al., 2010) also play important roles.

The effect of temperature was well defined by Heide \& Prestrud (2005), who concluded that temperatures below $12^{\circ} \mathrm{C}$ induce the growth stopping of apple and pear trees in a greenhouse, under stable and controlled conditions. For grapevine, Hendrickson et al. (2004) showed that small variations in temperature $\left(1-3^{\circ} \mathrm{C}\right)$ induce large differences in shoot growth cessation in cold climates. These authors also observed that, below $15^{\circ} \mathrm{C}$, the photosynthetic mechanism has limitations, and that, below $10^{\circ} \mathrm{C}$, leaves have higher levels of stomatal closure. The basal temperature reported for the vine is $10^{\circ} \mathrm{C}$ (Pouget, 1972; Koundouras et al., 1999; Leeuwen et al., 2004; Andreini et al., 2009). The effect of the photoperiod in grapevine was described by Garris et al. (2009), who observed growth cessation induction when there was less than or at least 12 hours of light without temperature alterations. According to Fennell \& Hoover (1991) and Heide (2008), the effect of the photoperiod on shoot growth cessation is highly dependent on temperature variation. However, the temperature effect seems to be related to the minimum temperatures, as described by Tanino et al. (2010). Therefore, the plant growth control mechanism, under field conditions, is affected by several factors that interact with each other.

\section{Conclusions}

1. Shoot development shows a polynomial pattern for 'Merlot' and 'Cabernet Sauvignon'.

2. Shoot growth cessation occurs during the initial ripening phase of the grapes at São Joaquim, Santa Catarina State, Brazil.

3 . Temperature and photoperiod cause grapevine shoots to cease growth in the highland regions of Santa Catarina, Brazil.

\section{Acknowledgments}

To Villa Francioni Agro Negócios S.A., for making available the vineyards to carry out this research.

\section{References}

ANDREINI, L.; VITI, R.; SCALABRELLI, G. Study on the morphological evolution of bud break in Vitis vinifera L. Vitis, v.48, p.153-158, 2009.

BORGHEZAN, M.; GAVIOLI, O.; PIT, F.A.; SILVA, A.L. da. Comportamento vegetativo e produtivo da videira e composição da uva em São Joaquim, Santa Catarina. Pesquisa Agropecuária Brasileira, v.46, p.398-405, 2011.

CHAO, W.S.; FOLEY, M.E.; HORVATH, D.P.; ANDERSON, J.V. Signals regulating dormancy in vegetative buds. International Journal of Plant Developmental Biology, v.1, p.49-56, 2007.

CLOETE, H.; ARCHER, E.; HUNTER, J.J. Shoot heterogeneity effects on Shiraz/Richter 99 grapevines. I. Vegetative growth. South African Journal of Enology and Viticulture, v.27, p.68-75, 2006.

COIPEL, J.; RODRÍGUEZ-LOVELLE, B.; SIPP, C.; VAN LEEUWEN, C. Terroir effect, as a result of environmental stress, depends more on soil depth than on soil type (Vitis vinifera L. cv. Grenache Noir, Côtes du Rhône, France, 2000). Journal 
International des Sciences de la Vigne et du Vin, v.40, p.177-185, 2006.

CONDE, C.; SILVA, P.; FONTES, N.; DIAS, A.C.P.; TAVARES, R.M.; SOUZA, M.J.; AGASSE, A.; DELROT, S.; GERÓS, H. Biochemical changes throughout grape berry development and fruit and wine quality. Food, v.1, p.1-22, 2007.

FALCÃO, L.D.; CHAVES, E.S.; BURIN, V.M.; FALCÃO, A.P.; GRIS, E.F.; BONIN, V.; BORDIGNON-LUIZ, M.T. Maturity of Cabernet Sauvignon berries from grapevines grown with two different training systems in a new grape growing region in Brazil. Ciencia e Investigación Agraria, v.35, p.271-282, 2008.

FENNELL, A.; HOOVER, E. Photoperiod influences growth, bud dormancy, and cold acclimation in Vitis labruscana and V. riparia. Journal of the American Society for Horticultural Science, v.116, p.270-273, 1991.

FOURNIOUX, J.C. Foliar influences on the vegetative development of grapevine. Journal International des Sciences de la Vigne et du Vin, v.31, p.165-183, 1997.

GACHONS, C.P. des; VAN LEEUWEN, C.; TOMINAGA, T.; SOYER, J.P.; GAUDILLÈRE, J.P.; DUBOURDIEU, D. Influence of water and nitrogen deficit on fruit ripening and aroma potential of Vitis vinifera L cv Sauvignon Blanc in field conditions. Journal of the Science of Food and Agriculture, v.85, p.73-85, 2005.

GARRIS, A.; CLARK, L.; OWENS, C.; MCKAY, S.; LUBY, J.; MATHIASON, K.; FENNELL, A. Mapping of photoperiod-induced growth cessation in the wild grape Vitis riparia. Journal of the American Society for Horticultural Science, v.134, p.261-272, 2009.

GRIS, E.F.; BURIN, V.M.; BRIGHENTI, E.; VIEIRA, H.; BORDIGNON-LUIZ, M.T. Phenology and ripening of Vitis vinifera L. grapes varieties in São Joaquim, southern Brazil: a new South American wine growing region. Ciencia e Investigación Agraria, v.37, p.61-75, 2010.

HEIDE, O.M. Interaction of photoperiod and temperature in the control of growth and dormancy of Prunus species. Scientia Horticulturae, v.115, p.309-314, 2008.

HEIDE, O.M.; PRESTRUD, A.K. Low temperature, but not photoperiod, controls growth cessation and dormancy induction and release in apple and pear. Tree Physiology, v.25, p.109-114, 2005.

HENDRICKSON, L.; BALL, M.C.; WOOD, J.T.; CHOW, W.S.; FURBANK, R.T. Low temperature effects on photosynthesis and growth of grapevine. Plant, Cell and Environment, v.27, p.795-809, 2004.

HUNTER, J.J.; VISSER, J.H. The effect of partial defoliation on growth characteristics of Vitis vinifera L. cv. Cabernet Sauvignon. I. Vegetative growth. South African Journal of Enology and Viticulture, v.11, p.18-25, 1990.

KOUNDOURAS, S.; VAN LEEUWEN, C.; SEGUIN, G.; GLORIES, Y. Influence of water status on vine vegetative growth, berry ripening and wine characteristics in Mediterranean zone (example of Nemea, Greece, variety Saint-George, 1997). Journal
International des Sciences de la Vigne et du Vin, v.33, p.149-160, 1999.

LEEUWEN, C. van; FRIANT, P.; CHONÉ, X.; TREGOAT, O.; KOUNDOURAS, S.; DUBOURDIEU, D. The influence of climate, soil, and cultivar on terroir. American Journal of Enology and Viticulture, v.55, p.207-217, 2004.

LENZ, M.S.; ISAACS, R.; FLORE, J.A.; HOWELL, G.S. Vegetative growth responses of Pinot Gris (Vitis vinifera L.) grapevines to infestation by Potato Leafhoppers (Empoasca fabae Harris). American Journal of Enology and Viticulture, v.60, p.130-137, 2009.

LORENZ, D.H.; EICHHORN, K.W.; BLEIHOLDER, H.; KLOSE, R.; MEIER, U.; WEBER, E. Phenological growth stages of the grapevine (Vitis vinifera L. ssp. vinifera) - codes and descriptions according to the extended BBHC scale. Australian Journal of Grape and Wine Research, v.1, p.100-103, 1995.

MIELE, A.; RIZZON, L.A.; ZANUS, M.C. Discrimination of Brazilian red wines according to the viticultural region, varietal, and winery origin. Ciência e Tecnologia de Alimentos, v.30, p.268-275, 2010.

MOTA, C.S.; AMARANTE, C.V.T. do; SANTOS, H.P. dos; ZANARDI, O.Z. Comportamento vegetativo e produtivo de videiras 'Cabernet Sauvignon' cultivadas sob cobertura plástica. Revista Brasileira de Fruticultura, v.30, p.148-153, 2008.

OLSEN, J.E. Light and temperature sensing and signaling in induction of bud dormancy in woody plants. Plant Molecular Biology, v.73, p.37-47, 2010

PETRIE, P.R.; TROUGHT, M.C.T.; HOWELL, G.S. Fruit composition and ripening of Pinot Noir (Vitis vinifera L.) in relation to leaf area. Australian Journal of Grape and Wine Research, v.6, p.46-51, 2000.

POUGET, R. Considérations générales sur le rythme végétatif et la dormance des bourgeons de la vigne. Vitis, v.11, p.198-217, 1972.

ROBINSON, S.P.; DAVIES, C. Molecular biology of grape berry ripening. Australian Journal of Grape and Wine Research, v.6, p.175-188, 2000.

SMITHYMAN, R.P.; HOWELL, G.S.; MILLER, D.P. Influence of canopy configuration on vegetative development, yield, and fruit composition of Seyval blanc grapevines. American Journal of Enology and Viticulture, v.48, p.482-491, 1997.

STATSOFT. STATISTICA for Windows: computer program manual. Version 6.0. Tulsa: Statsoft, 2001.

TANINO, K.K.; KALCSITS, L.; SILIM, S.; KENDALL, E.; GRAY, G.R. Temperature-driven plasticity in growth cessation and dormancy development in deciduous woody plants: a working hypothesis suggesting how molecular and cellular function is affected by temperature during dormancy induction. Plant Molecular Biology, v.73, p.49-65, 2010.

TREGOAT, O.; VAN LEEUWEN, C.; CHONÉ, X.; GAUDILLÈRE, J.-P. Étude du régime hydrique et de la nutrition azotée de la vigne par des indicateurs physiologiques: influence sur le comportement de la vigne et la maturation du raisin (Vitis vinifera L. cv. Merlot, 
2000, Bordeaux). Journal International des Sciences de la Vigne et du Vin, v.36, p.133-142, 2002.

VASCONCELOS, M.C.; GREVEN, M.; WINEFIELD, C.S.; TROUGHT, M.C.T.; RAW, V. The flowering process of Vitis vinifera: a review. American Journal of Enology and Viticulture, v.60, p.411-434, 2009.
VICTOR, K.J.; FENNELL,A.Y.; GRIMPLET, J.Proteomic analysis of shoot tissue during photoperiod induced growth cessation in $V$. riparia Michx. grapevines. Proteome Science, v.8, p.1-17, 2010.

WAKE, C.M.F.; FENNELL, A. Morphological, physiological and dormancy responses of three Vitis genotypes to short photoperiod. Physiologia Plantarum, v.109, p.203-210, 2000.

$\overline{\text { Received on September 21, } 2011 \text { and accepted on January } 2^{\text {nd }}, 2012}$ 